\title{
Rice Straw Composting by Cellulolytic Bacteria Isolate and Its Application on Rice in Acid Sulfate Soils
}

\author{
Yuli Lestari ${ }^{{ }^{*}}$,Eni Maftu'ah ${ }^{1}$ and Wahida Annisa ${ }^{1}$ \\ ${ }^{1}$ Indonesian Swampland Agricultural Research Institute(ISARI), Banjarbaru, Kalimantan Selatan
}

\begin{abstract}
High acidity in acid sulfate soils due to pyrite oxidation results in increased $\mathrm{Al}^{3+}$ and $\mathrm{Fe}^{2+}$ activity which inhibits the growth of rice plants. The application of organic matter (compost) is one of the technology to manage acid sulfate soil. This study aims to obtain cellulolytic bacterial isolates that are superior in composting and improving rice growth in acid sulfate soil. The experiment carries out in the laboratory and glasshouse of the Indonesian Swampland Agriculture Research Institute (ISARI), Banjarbaru, Indonesia on May-November 2017. The experimental to obtain cellulolytic bacteria and water content that can accelerate composting is arranged by factorial using a complete randomized design with three replication First factor were cellulolytic bacteria application (without application/control, BS 1.6, BS 1.9, BS 2.2 and BS 2.5), while the second factor was water content $(50 \%, 100 \%$, and $150 \%)$. The effect of compost application with cellulolytic bacterial to rice growth arranged by factorial completely randomized design with 3 replications. The first factor was cellulolytic bacteria application (without application/control, BS 1.6, BS 1.9, and BS 2.2), while the second factor was composting condition (muddy waterlogged and waterlogged $5 \mathrm{~cm} \mathrm{depth}$ ). The result showed that the ability of cellulolytic bacteria to reduce $\mathrm{C} / \mathrm{N}$ straw was not different. Only differences in water content affect the reducing $\mathrm{C} / \mathrm{N}$ ratio of straw. The average $\mathrm{C} / \mathrm{N}$ ratio of straw compost made with $50 \%, 100 \%$, and $150 \%$ water content is $35.59 ; 29.71$, and 29.21 . Application of compost made under muddy waterlogged and inoculated BS1.9 and BS2.2 can increase the number of tillers, while those inoculated BS1.6 and BS1.9 can increase the rice shoot dry weight of Inpara 2. The suggest that cellulolytic bacterial inoculation can improve the quality of compost so that the growth of rice is better.
\end{abstract}

\section{Introduction}

The tidal swamp has an important role in the Indonesian food supply in line with the increasing population and conversion of agricultural land, especially in Java Island. One type of soil that becomes a potential for agricultural development in this area is acid sulfate soil. In Indonesia, there is approximately 6.71 million ha of the acid sulfate soil which great potential for agricultural development, especially for rice cultivation. It is due to the availability of abundant water, especially overflow type $\mathrm{A}$ and $\mathrm{B}$, flat topography, access to reach the usual location by land and water (river), and extensive land ownership [1].

Acid sulfate soil is characterized either by a pyrite $\left(\mathrm{FeS}_{2}\right)$ layer or sulfuric horizons. The pyrite is mainly causing high acidity in the land, as well as the reduction of soil fertility. The increased acidity also increases of aluminum (Al) and other microelements such as Fe and Mn. Such a condition can also be poisonous to plants. On the other side, due to the high level of soil acidity, macroelements such as phosphorous are deficient. In rice cultivation, $\mathrm{Fe}$ toxicity causes decreases in crop yields, $12-100 \%$ [2].

The utilization of organic matter is. one alternative to overcome the problem of acid sulfate soils. Organic material increases soil $\mathrm{pH}$, the fertility of acid soils, but reducing the availability of toxic elements such as $\mathrm{Fe}$ and Al. However, the application of raw organic material can result in the immobilization of nutrients [3]. Thus, to accelerate the composting required the addition of decomposers such as cellulolytic bacteria. Organic materials that can be composted include manure and in-situ weed (grass, ratpurun, kalakai), as well as agriculture waste (straw, stover, corn cobs, oil palm empty fruit bunches).

Agricultural waste such as rice straw, corn stover, soybean stems, weeds, and oil empty bunches is composed of lignocellulose compounds. This compounds three polymers, namely cellulose, hemicellulose, and lignin [4] (Perez et al., 2002). When lignocellulose hydrolyzed perfectly it produces glucose molecules. However, the degradation of lignocellulose compounds is very difficult because of the crystalline structure of cellulose [5]. Cellulose is the main carbohydrate synthesized by plants and occupies nearly $60 \%$ of the constituent components of plant structure.

Hydrolysis of cellulose to glucose can take place physically, chemically, and biologically. The process of cellulose hydrolysis is biologically carried out by the cellulase enzyme. Cellulase is an enzyme that can break the binding of glucoside $p-1,4$ in cellulose. This enzyme consists of three components, namely endo 1,4 $\beta$-glucanase, Exo 1,4 $\beta$-glucanase (cellobiohydrolase), and $\beta$ glucosidase which can break down crude fiber components into dissolved carbohydrates [6]. Endoglucanase breaks down cellulose randomly into cello-oligosaccharides. Exoglucanase breaks down cellulose from non-reduction end chains by releasing cellobiose, whereas $\beta$-glucosidase hydrolyzes cellobiose and oligosaccharides into glucose, which can then be used as energy, by microbes [7].

Cellulase enzymes are produced by several microbes, including bacteria, fungi, and actinomycetes. Some bacteria that show cellulase activity include Corynebacterium, Aeromonas [8]. Fungi that have

Corresponding author : yulibalittra70@yahoo.com 
cellulase activity include Rhizopus sp., Aspergillus terreus, Aspergillus niger, Curvularia lunata, A. nidulans, A. fumigates, Penicillium sp., Fusarium rosium, and Trichoderma viridae [9].

One factor that determines the success rate of the utilization of organic material is the level of maturity (citation). While the organic material derived from plants contains high cellulose and is difficult to decompose, the accelerated maturity of this decomposition, is necessary to conduct, particularly of the microbial application. The objective of this study was to obtain cellulolytic bacterial isolates that are superior in composting and improving rice growth in acid sulfate soil.

\section{Materials and Methods}

\subsection{Rice straw decomposition}

The experiment was carried out at the Soil and Plant Laboratory, Indonesian Swampland Agriculture Research Institute (ISARI), Banjarbaru, Indonesia in May-August 2017. This study was carried out using a factorial, completely randomized design with three replicates. The first factor was the variation of cellulolytic bacterial isolates, i.e. (i) without microbes or control, (ii) BS1.6, (iii) BS1.9, (iv) BS2.2, and (v) BS2 .5. The second factor was the variation of water content, which is $50 \%, 100 \%$, and $150 \%$. In the initial stage, $250 \mathrm{~g}$ of fresh straw was put into a container (pot), then water was added according to the treatment. After that, cellulolytic bacterial isolates were sown into the straw, then incubated for four weeks in a place that was not exposed to direct sunlight at room temperature $\left( \pm 28^{\circ} \mathrm{C}\right)$. The $\mathrm{C} / \mathrm{N}$ ratio was measured to all samples before and after the treatment.

\subsection{Compost application}

Acid sulfate soil was used in this experiment taken from the Belandean experimental station, Alalak Village, Mandastana District, Barito Kuala Regency, South Kalimantan on S 03'16'90,5'; E114'60'39,5'. The compost that was obtained in the previous activity was applied to the plant model, in the case Inpara 2 which is in one of the superior swamp rice in Indonesia. This activity carried out in ISARI Greenhouse in August-November 2017 using the design of completely randomized in factorially with 3 replication. The treatments start with cellulolytic bacteria that is the application to straw used as compost, namely (i)without cellulolytic bacteria (control), (ii) BS1.6, (ii) BS1.9 and BS2.2 and the compost making condition, namely (a) muddy waterlogged (b) waterlogged $5 \mathrm{~cm}$ depth. Organic material as compost substrate is rice straw.

Initially, rice straw was placed in the pot containing acid sulfate soil. After adding water and cellulolytic bacteria according to treatment incubated for 4 weeks. Two weeks before planting rice Inpara 2, the experimental pot was limed at a dose of $2 \mathrm{t}^{\mathrm{h}} \mathrm{ha}^{-1}$. Basic fertilizers such as urea $226 \mathrm{~kg} \cdot \mathrm{ha}^{-1}$ and $\mathrm{KCl} 150$ $\mathrm{kg} . \mathrm{ha}^{-1}$ were applied when the plant was 1 week and 4 weeks old. Fertilization $\mathrm{P}$ is carried out at planting with a dose of $200 \mathrm{~kg}^{-1}$ TSP. Maintenance included watering using local well water and intensive eradication of pests and diseases. Plants were maintained until the maximum vegetative phase, harvested at 8 weeks after plan (WAP).

Soil chemical properties observed before the experiment included $\mathrm{pH}, \mathrm{C}$-organic, N-total, Alavailable, and Fe. Observations on plant height, number of the tiller, and plant dry weight were carried out during the maximum The data obtained in this experiment were analyzed statistically using SAS software Portable 9.1.3. Analys is of variance was done to determine the treatment difference. The Duncan multiple range test (DMRT) was used to compare treatment means at $\mathrm{P}<0.01$ or $\mathrm{P}<0.05$.

\section{Result and Discussion}

\subsection{Rice Straw Decomposition}

The organic material used as a substrate in compost is rice straw. The chemical composition of straw is presented in Table 1 . Table 1 showed that rice straw contains high $\mathrm{C}$ and $\mathrm{N}$, namely $51.48 \%$ and $1.316 \%$, respectively, and low water content $(4.925 \%)$. The higher the nitrogen content of decomposed organic matter, the faster the organic material decomposes, because the decomposing microbes require nitrogen for its growth [10] (Sriharti, 2008). According to Pandebesie dan Rayuanti [11], the low water content (humidity) decreases the efficiency of decomposition of organic matter due to lack of water to dissolve organic matter degraded by microbes as a source of energy.

The $\mathrm{C} / \mathrm{N}$ ratio is one of the mature indicators of organic matter that affects organic decomposition. An effective decomposition process of organic matter occurs at a $\mathrm{C} / \mathrm{N}$ ratio between $30-40$. At a $\mathrm{C} / \mathrm{N}$ ratio between 30-40, microbes get enough $\mathrm{C}$ for energy and $\mathrm{N}$ for protein synthesis [12]. If the $\mathrm{C} / \mathrm{N}$ ratio is too high, the microbes will lack $\mathrm{N}$ for protein synthes is so that decomposition is slow [13]. In this study, the $\mathrm{C} / \mathrm{N}$ ratio of straw before the decomposition process was high (39.12).

Tabel 1. Chemical composition of rice straw before decomposition

\begin{tabular}{|l|c|}
\hline Chemical composition & Value \\
\hline C-organic $(\%)$ & 51.48 \\
\hline $\mathrm{N}(\%)$ & 1.32 \\
\hline $\mathrm{C} / \mathrm{N}$ & 39.12 \\
\hline Water content $(\%)$ & 4.93 \\
\hline
\end{tabular}

Based on the chemical analysis of compost after incubated, the $\mathrm{C}$ content is significantly affected by water content but not the cellulolytic bacterial 
application (Table 2). Table 2 also showed that the interaction between cellulolytic bacterial and water content does not affect the $\mathrm{C}$ content of straw compost. The average $\mathrm{C}$ content of straw compost made at $150 \%$ water content is lower than $50 \%$ and $100 \%$. When compared with the $\mathrm{C}$ content of straw before the composting process $(51.48 \%)$, the treatment of water content decreases the $\mathrm{C}$ content of decomposition products of rice straw. Levels of $\mathrm{C}$ treated with $50 \%$, $100 \%$, and $150 \%$ water content decreased by $13.27 \%$, $11.95 \%$, and $15.79 \%$, respectively. According to Wijanarko et al. [14], the decreas ed levels of C organic matter during the decomposition process because microbes utilize carbon compounds (C) in organic materials as an energy source. Water content (humidity) between $40-60 \%$ is the optimum range for microbial metabolism. If the humidity is below $40 \%$, microbial activity will decrease. If the water content is greater than $60 \%$, nutrients will be washed, and the volume of air will be reduced. Consequently, microbial activity will decrease. In this study, the most rapid decline in $\mathrm{C}$ levels occurred at $150 \%$ water content, whereas decomposition is the fastest process.

Tabel 2. Effect of cellulolytic bacterial inoculation on $\mathrm{C}$ levels of composted straw with different water contents.

\begin{tabular}{|l|c|c|c|c|}
\hline \multirow{2}{*}{$\begin{array}{l}\text { Cellulolytic } \\
\text { bacteria } \\
\text { inoculation }\end{array}$} & \multicolumn{3}{|c|}{ Water content (\%) } & \multirow{2}{*}{ Average } \\
\cline { 2 - 4 } & 50 & 100 & 150 & \\
\hline $\begin{array}{l}\text { Without } \\
\text { inoculation }\end{array}$ & 44,88 & 45.79 & 43.07 & 44.58 \\
\hline BS1.6 & 43.66 & 45.83 & 43.36 & 44.29 \\
\hline BS19 & 45.57 & 44.76 & 43.20 & 44.51 \\
\hline BS22 & 45.28 & 46.34 & 43.88 & 45.17 \\
\hline BS25 & 45.83 & 43.94 & 43.26 & 43.68 \\
\hline Average** & $\begin{array}{c}44.65 \\
\mathrm{~A}\end{array}$ & $\begin{array}{c}45.33 \\
\mathrm{~A}\end{array}$ & $\begin{array}{c}43.35 \\
\mathrm{~B}\end{array}$ & $(-)$ \\
\hline
\end{tabular}

** Means with the different capital letter within row differ significantly by Duncan DMRT $(\mathrm{p}<0.01)$

Nitrogen is an organic material decomposition product. The results showed that cellulolytic bacteria application. water content at the time of composing. and the interaction of both did not affect the $\mathrm{N}$ level of straw compost (Table 3). The average $\mathrm{N}$ content of straw compost is $1.42 \%$. This value is higher than the $\mathrm{N}$ content of straw before the composting process $(1.32 \%)$. The cause is nitrogen will be released in the decomposition process of an organic matter involving microbes. Thus. naturally, the $\mathrm{N}$ content of straw compost is higher than the initial substrate.

The $\mathrm{C} / \mathrm{N}$ ratio is an indicator of the organic matter decomposition process. The greater $\mathrm{C} / \mathrm{N}$ value of decomposition products indicates that the organic material has not completely decomposed. On the other hand. the lower $\mathrm{C} / \mathrm{N}$ value of decomposition products indicates that organic material has decomposed. The results showed that the $\mathrm{C} / \mathrm{N}$ ratio of rice straw compost is significantly affected by water content but not the cellulolytic bacteriat (Table 4). Table 4 also shows that the interaction between cellulolytic bacterial and water content does not affect the $\mathrm{C} / \mathrm{N}$ ratio of rice straw compost. According to Widarti et al. [15], the water content greatly influences the process of decomposition of organic matter that plays a role in the process of microbial metabolism. The average $\mathrm{C} / \mathrm{N}$ ratio of straw compost made at $100 \%$ and $150 \%$ moisture content is not statistically different but both are significantly different compared to $50 \%$.

Tabel 3. Effect of cellulolytic bacterial inoculation on $\mathrm{N}$ content of composted straw with different water contents

\begin{tabular}{|l|c|c|c|c|}
\hline \multirow{2}{*}{$\begin{array}{l}\text { Cellulolytic } \\
\text { bacteria }\end{array}$} & \multicolumn{3}{|c|}{ Water content (\%) } & \multirow{2}{*}{ Average } \\
\cline { 2 - 4 } & 50 & 100 & 150 & \\
\hline $\begin{array}{l}\text { Without } \\
\text { inoculation }\end{array}$ & 1.41 & 1.54 & 1.63 & 1.52 \\
\hline BS16 & 1.39 & 1.24 & 1.47 & 1.37 \\
\hline BS19 & 1.27 & 1.57 & 1.30 & 1.38 \\
\hline BS22 & 1.23 & 1.09 & 1.33 & 1.22 \\
\hline BS25 & 1.33 & 1.68 & 1.78 & 1.60 \\
\hline Average & 1.33 & 1.42 & 1.50 & $(-)$ \\
\hline
\end{tabular}

When compared with the level of compost C. it shows that the decrease in straw $\mathrm{C}$ is not directly proportional to the increase in compost $\mathrm{N}$ level. It is suspected that some of the nitrogen in the decomposition product is volatilized. The compost $\mathrm{C} /$ $\mathrm{N}$ ratio value made at $50 \%$. 100\%. and $150 \%$ water content is 35.59; 29.71 and 29.21. When compared with the $\mathrm{C} / \mathrm{N}$ ratio value of straw before composting (39.12). each decreased by $9.02 \%$. 24.05\% and $25.33 \%$. However. the results of the decomposition of organic material have not suitable the requirements of SNI 19-7030-2004, namely 10-20.

Tabel 4. Effect of cellulolytic bacterial inoculation on $\mathrm{C} / \mathrm{N}$ ratio composted straw with different water contents

\begin{tabular}{|l|c|c|c|c|}
\hline \multirow{2}{*}{$\begin{array}{l}\text { Cellulolytic } \\
\text { bacteria }\end{array}$} & \multicolumn{3}{|c|}{ Water content (\%) } & \multirow{2}{*}{ Average } \\
\cline { 2 - 4 } & 50 & 100 & 150 & \\
\hline $\begin{array}{l}\text { Without } \\
\text { inoculation }\end{array}$ & 40.54 & 26.67 & 26.54 & 30.58 \\
\hline BS1.6 & 37.89 & 28.74 & 26.02 & 30.87 \\
\hline BS1.9 & 36.13 & 29.06 & 33.61 & 32.93 \\
\hline BS2.2 & 31.23 & 39.79 & 33.96 & 34.85 \\
\hline BS2.5 & 33.15 & 26.33 & 24.85 & 28.11 \\
\hline Average** & $\begin{array}{c}35.59 \\
\text { A }\end{array}$ & $\begin{array}{c}29.71 \\
\text { B }\end{array}$ & $\begin{array}{c}29.21 \\
\text { B }\end{array}$ & $(-)$ \\
\hline
\end{tabular}

** Means with the different capital letter within row differ significantly by Duncan DMRT $(\mathrm{p}<0.01)$

\subsection{Application rice of straw compost inoculates cellulolytic bacteria to rice in acid sulfate soil.}

Acid sulfate soils used in this study are classified as very acidic $\left(\mathrm{pH} \mathrm{H}_{2} \mathrm{O}=4.16\right)$ with high C-organic content $(0.248 \%)$ and moderate N-total $(3.69 \%)$ (Table 
5). Table 5 also shows that Al levels were $9.77 \mathrm{cmol}$ $\mathrm{kg}^{-1}$. According to Sunarko [16]. that at acidic $\mathrm{pH}$ $(<4.5)$. aluminum activity in binding phosphorus in high soil solution. Therefore. to increase the productivity of acid sulfate soils used for this study. It is necessary to provide high-quality organic material to chelate aluminum.

Tabel 5. Initial characteristics of acid sulfate soil before the experiment

\begin{tabular}{|l|c|c|}
\hline $\begin{array}{l}\text { Chemical } \\
\text { characteristic }\end{array}$ & Value & Criteria \\
\hline pH $\mathrm{H}_{2} \mathrm{O}$ & 4.16 & Very Acid \\
\hline C-organik (\%) & 3.69 & High \\
\hline N-total $(\%)$ & 0.25 & Moderate \\
\hline Al-dd $\left(\mathrm{c} \mathrm{mol.kg}{ }^{-1}\right)$ & 9.77 & \\
\hline
\end{tabular}

\subsection{Plant growth}

Plant height is one of the most frequent and easily observed indicators of plant growth. The results showed that cellulolytic bacteria application of rice straw used as compost. the condition of composting. and the interaction of both did not affect the height of rice plants at $8 \mathrm{WAP}$. The average height of Inpara 2 rice plants at $8 \mathrm{MST}$ is $87.23 \mathrm{~cm}$. According to Doberman \& Fairhurst [17], nutrients that have an important role in plant growth. including plant height. are nitrogen. Possibility. the height of rice plants did not differ between treatments related to the dose of $\mathrm{N}$ fertilizer applied equally. namely $90 \mathrm{~kg} \mathrm{~N}$. ha ${ }^{-1}(226 \mathrm{~kg}$ urea.ha ${ }^{-1}$ ) and the element $\mathrm{N}$ released from straw decomposition is also no different.

Tabel 6. The effect of cellulolytic bacteria to rice straw and the condition of composting on shoot dry weight of Inpara 2 varieties at WAP

\begin{tabular}{|c|c|c|c|}
\hline \multirow{2}{*}{$\begin{array}{l}\text { Cellulolytic } \\
\text { bacteria } \\
\text { application }\end{array}$} & \multicolumn{3}{|c|}{ Composting condition } \\
\hline & $\begin{array}{c}\text { Muddy } \\
\text { waterlogged }\end{array}$ & $\begin{array}{l}\text { Waterlogged } \\
5 \mathrm{~cm} \text { depth }\end{array}$ & Average \\
\hline $\begin{array}{l}\text { Without } \\
\text { application }\end{array}$ & 72.33 & 72.00 & 72.17 \\
\hline BS1.6 & 75.00 & 77.33 & 76.17 \\
\hline BS1.9 & 76.33 & 76.67 & 76.50 \\
\hline BS2.2 & 76.00 & 78.00 & 76.80 \\
\hline Average & 74.92 & 75.82 & $(-)$ \\
\hline
\end{tabular}

Table 7 showed the interaction between cellulolytic bacteria in rice straw compost and the changing conditions of the number of Inpara 2 varieties of rice seedlings at $8 \mathrm{WAP}$. Cellulolytic bacteria in the straw compost has a positive effect on the number of rice tillers in muddy waterlogged but not in waterlogged. Under the former, that composted from straw was inoculated in BS 1.9 and BS 2.2. the number of rice tillers more than without treated. Presumably related to P-available due to inoculation of BS1.9 and BS2.2 in straw used as compost. Susanti et al. [18] reported that the number tiller of Inpari 13 which given organic material Crotalaria juncea is higher than
Sesbania rostata. The chemical analys is shows that both plants contain $\mathrm{P}$ of $3.18 \%$ and $1.22 \%$. respectively.

Tabel 7. The effect of cellulolytic bacterial application to rice straw and the condition of the composting on the number of the tiller of Inpara 2 varieties at 8 WAP.

\begin{tabular}{|l|c|c|c|}
\hline \multirow{2}{*}{$\begin{array}{l}\text { Cellulolytic } \\
\text { bacteria } \\
\text { application }\end{array}$} & $\begin{array}{c}\text { Decomposition condition* } \\
\text { waterlogged }\end{array}$ & $\begin{array}{c}\text { Waterlogged } \\
5 \text { cm depth }\end{array}$ & Average \\
\hline $\begin{array}{l}\text { Without } \\
\text { application }\end{array}$ & $16.67^{\mathrm{b}}$ & $23.33^{\mathrm{a}}$ & 19.50 \\
\hline BS1.6 & $20.00^{\mathrm{ab}}$ & $22.67^{\mathrm{a}}$ & 21.33 \\
\hline BS1.9 & $23.33^{\mathrm{a}}$ & $23.00^{\mathrm{a}}$ & 23.17 \\
\hline BS2.2 & $23.33^{\mathrm{a}}$ & $24.50^{\mathrm{a}}$ & 23.80 \\
\hline Average & 20.83 & 23.00 & $(+)$ \\
\hline
\end{tabular}

* Means with the different litter within row and column differ significantly by Duncan DMRT $(\mathrm{p}<0.05)$

Shoot dry weight is the result of the accumulation of photosynthesis which is allocated to the upper plants. The results showed an interaction between cellulolytic bacteria in rice straw compost and an overhaul condition of the shoot dry weight of rice varieties of Inpara 2 at 8 MST (Table 8). Cellulolytic bacteria of straw compost has a positive effect on the shoot dry weight of rice. particularly in the muddy waterlogged not in the waterlogged. In acid sulfate soils. the activity of Al in non-submerged conditions is higher than in submerged. According to Tamad \& Hanudin [19]. the organic acids contained organic materials that chelated metals. such as $\mathrm{Al}$ and Fe. so that the availability of $\mathrm{P}$ in the soil increases. With increasing $\mathrm{P}$ available plant growth increases as reflected in the increased dry weight of plants.

Tabel 8. The effect of cellulolytic bacterial application to rice straw and the condition of composting on the rice plant height of Inpara 2 varieties at 8 WAP.

\begin{tabular}{|c|c|c|c|}
\hline \multirow{2}{*}{$\begin{array}{l}\text { Cellulolytic } \\
\text { bacteria }\end{array}$} & \multicolumn{3}{|c|}{ Composting condition* } \\
\hline & $\begin{array}{c}\text { Muddy } \\
\text { waterlogged }\end{array}$ & $\begin{array}{l}\text { Waterlogged } \\
5 \mathrm{~cm} \text { depth }\end{array}$ & Average \\
\hline $\begin{array}{l}\text { Without } \\
\text { application }\end{array}$ & $9.50^{\mathrm{c}}$ & $14.10^{\mathrm{b}}$ & 12.60 \\
\hline BS1.6 & $14.30^{\mathrm{ab}}$ & $15.13^{\mathrm{ab}}$ & 14.72 \\
\hline BS1.9 & $18.65^{\mathrm{a}}$ & $12.23^{\mathrm{bc}}$ & 15.40 \\
\hline $\mathrm{BS} 2.2$ & $12.60^{\mathrm{bc}}$ & $16.05^{\mathrm{ab}}$ & 13.98 \\
\hline Average & 13.70 & 14.50 & $(+)$ \\
\hline
\end{tabular}

* Means with the different letter within row and column differ significantly by Duncan DMRT $(\mathrm{p}<0.05)$

\section{Conclusion}

Cellulolytic bacteria used in this study did not accelerate the composting of organic material. Only the difference in water content accelerates the composting of organic matter. The average $\mathrm{C} / \mathrm{N}$ ratio of straw compost made at $100 \%$ and $150 \%$ water content is 
29.71 and 29.21. respectively. which is higher than $50 \%$ (35.59).

In the pot experiments. the tiller number of Inpara 2 variety at 8 WAP which were planted in acid sulfate soils which applicated of straw compost inoculated cellulolytic bacteria BS1.9 and BS2.2 on the muddy waterlogged higher than control. Shoot dry weight increased by $50.53 \%$ and $96.32 \%$. respectively. due to the composting of straw inoculated with BS1.6 and BS1.9 under the muddy waterlogged

\section{References}

1. M. Noor. Pertanian Lahan Gambut: Potensi dan Kendala. Kanisius. Yogyakarta. (2001)

2. K.L Sahrawat. Irom Toxicity in wetland rice and the role of other nutrients. Journal of Plant Nutrition. 27 (5), (2005)

3. A.B. Fahmi. Radjagukguk \& B.H. Purwanto. Phosphate anf ferro Solubility on Acid Sulfate Soil treated with Rice Straw. J. Tanah Trop. 14 (2):151-156, (2009)

4. J. Perez. T. Munoz. Rubia \& J. Martinez. Biodegradation and biological treatments of cellulose. hemicelluloses and lignin: an overview. Int. Microbiol. 5:53-63, (2002)

5. Koesnandar, Helianti \& N. Nurhayati. Recent development in the bioconversion of lignocelluloses into ethanol. Microbiology Indonesia. 2 (3):101-102, (2008)

6. R.I. Howard. E. Abotsi. El. Jansen van Rensburg \& S. Howard. African Journal of Biotechnology. 2 (12):602-619, (2003)

7. M. Lamid. Evaluasi kecernaan bahan organic dan serat kasar pada jerami padi menggunakan bakteri selulolitik. Preceding National Conference on Green Technology for Better Future. UIN Maulana Malik Ibrahim Malang, (2010).

8. M.A.P. Utomo \& M. Shovitri. Bakteri tanah pendegradasi bahan organic Desa Talango. Pulau Poteran. Sumenep. Jurnal Sains dan Semi Pomits. 3 (2):80-83, (2014)

9. S.P. Gautama. P.S. Bundela. A.K. Pandey. Jamaluddin. M.K. Avasthi, \& S. Sarsaiyo. Diversity of cellulolytic microbes and the biodegradation of municipal solid wate by a potential strain. International Journal of Microbiology, (2012)

10. S.T. Sriharti. Pemanfaatan limbah pisang untuk pembuatan pupuk kompos menggunakan kompos rotary drum. Proseding Seminar Nasional Teknik Kimia dan tekstil. Yogyakarta, (2008)

11. E.S. Pandebesie \& D. Rayuanti. Pengaruh penambahan sekam pada proses pengomposan sampah domestik. Jurnal Lingkungan Tropis. 6 (1):31-40, (2013)

12. A. Ismayana, N.S. Indrasti, Suprihatin, A. Maddu \& A. Fredy. Faktor rasio $\mathrm{C} / \mathrm{N}$ awal dan laju aerasi pada proses composting bagassedan blotong. $J$. Tekn. Industri Pertanian. 22 (3):173-179, (2012)
13. Isroi. Kompos. Balai Penelitian Bioteknologi Perkebunan. Bogor, (2008)

14. A. Wijanarko, B.H. Purwanto. D.. Shiddieq \& D. Indradewa. Pengaruh kualitas bahan organic dan kesuburan tanah terhadap mineralisasi nitrogen dan serapan $\mathrm{N}$ oleh tanaman ubikayu di ultisol. 2 (2):1-14, (2012)

15. B.N. Widarti, W.K. Wardhani \& E. Sarwono. Pengaruh rasio $\mathrm{C} / \mathrm{N}$ bahan baku pada pembuatan kompos dari kubis dan kulit pisang. Jurnal Integrasi Proses. 5 (2):75-80, (2015)

16. H. Sunarko. Budidaya Kelapa Sawit di Berbagai Jenis Lahan. PT Agromedia Pustaka. Jakarta, (2014)

17. A. Dobermann and T. Fairhurst. Rice: Nutrient Disorders \& Nutrient Management. IRRI. Philiphines, (2000)

18. R.A. Susanti, T. Sumarni \& E. Widaryanto. Pengaruh bahan organic terhadap pertumbuhan dan hasil tanaman padi (Oryza sativa L.) varietas Inpari 13 sistem tanam jajar legowo. Jurnal Produksi Tanaman. 1 (5):455-463, (2013)

19. Tamad \& E. Hanudin. Kompetisi anion organic dan anorganik dalam membentuk komleks dengan allofan dalam upaya perbaikan ketersediaan fosfat pada andisol. Jurnal Tanah dan Lingkungan. 8 (2):126-137, (2008) 